\title{
PENGARUH PROMOSI TERHADAP KEPUTUSAN PEMBELIAN DI RESTORAN JAVANA BISTRO BANDUNG
}

\author{
Intan Lina Katrin, H.p Diyah Setyorini, Masharyono \\ Program Studi Manajemen Industri Katering, Fakultas Pendidikan Ilmu Pengetahuan \\ Sosial, Universitas Pendidikan Indonesia \\ Email : Intan@upi.edu
}

\begin{abstract}
This research have the the case of descent the segment market that had by Javana Bistro. This cases is happened cause of the competition, as a restaurant in Bandung. So that the efforts that had to make is to increase the decision of purchases consumer in with fixed the promotion program. The purposes of this research is to know the influence of program promotion with decision purchases. Research object is variable $(X)$ Promotion and $(Y)$ Decision Purchases. The method that used in this research is descriftive and verificative with spreaded of assessment to consumers in Javana Bistro. Technique analysis used software SPSS version 22 for windows of this research is regression. The result of this research is that program promotion is influence to decision purchases of consumers in Javana Bistro. Recommendation on this research is Javana Bistro have to increases dimension direct marketing. And also Javana Bistro can fix the choose of product cause this variable had the worst score in this research.
\end{abstract}

Key Words: Promotion, Decision Purchases

\begin{abstract}
ABSTRAK
Penelitian ini dilatar belakangi oleh menurunnya jumlah dan rendahnya pangsa pasar yang dimiliki oleh Javana Bistro. Hal ini terjadi karena tingginya tingkat persaingan, baik dari restoran sejenis maupun tidak sejenis. Maka dari itu upaya yang harus dilakukan Javana Bistro yaitu meningkatkan keputusan pembelian dengan memperbaiki program promosi. Tujuan penelitian ini untuk mengetahui adakah pengaruh promosi terhadap keputusan pembelian. Objek penelitian ini yaitu variabel (X) yaitu promosi sedangkan variabel $(\mathrm{Y})$ yaitu keputusan pembelian. Metode penelitian yang digunakan adalah deskriptif dan verifikatif, sedangkan pengumpulan data dengan cara kuesioner. Teknik analisi data dengan bantuan software SPSS Versi 22 For Windows menggunakan regresi linear sederhana. Hasil penelitian menujukkan bahwa promosi memiliki pengaruh terhadap keputusan pembeliaan. Saran dalam penelitian ini adalah Javana Bistro harus bisa meningkatkan dimensi pemasaran langsung, sedangkan mengenai keputusan pembelian diharapkan Javana Bistro dapat memperbaiki pilihan produk karena memiliki skor yang rendah dari konsumen. Kata Kunci: Promosi, Keputusan Pembelian
\end{abstract}




\section{Pendahuluan}

Sektor pariwisata mempunyai keunggulan dan potensi dalam menciptakan lapangan pekerjaan, penghasil devisa, juga sebagai sektor yang mampu menjaga kelestarian sosial dan budaya Indonesia serta lingkungan hidup masyarakatnya. Seiring dengan meningkatnya tingkat kesejahteraan masyarakat Indonesia, hal ini berdampak kepada tumbuh kembangnya pariwisata karena sudah menjadi kebutuhan bagi masyarakat.

Indonesia kaya dengan berbagai wisata budaya, keindahan wisata alam dan wisata kuliner sehingga Indonesia dikenal sebagai salah satu negara tempat wisata yang populer. Berdasarkan laporan bulanan Kementrian Pariwisata dan Ekonomi Kreatif, jumlah kunjungan wisatawan mancanegara menurut pintu masuk dan kebangsaan bulan Desember 2015 sebesar 986.339 jiwa. Pada data tersebut, Jawa Barat termasuk ke dalam jumlah kunjungan wisatawan mancanegara yang cukup besar yaitu sebesar 16.983 jiwa. (sumber: http://www.kemenpar.go.id/userfiles /Lapbu1\%20Desember\%202015_klasik(revisi).pdf/diaksespada:25februari2016:10:5).

Jawa Barat dikenal sebagai salah satu daerah yang memiliki objek wisata dan budaya yang beraneka ragam yang tersebar di berbagai kota. Daya tarik yang dimiliki oleh Jawa Barat meliputi pantai, pegunungan, seni budaya, heritage, kuliner dan pusat perbelanjaan yang potensial.

Usaha makanan yang mempunyai peluang yang baik bagi pengusaha adalah restoran. Menurut Peraturan Menteri Kesehatan RI No. 304/Menkes/Per/89 tentang persyaratan restoran, yang dimaksud restoran adalah satu jenis usaha jasa pangan yang bertempat di sebagian atau seluruh bangunan yang permanen dilengkapi dengan peralatan dan perlengkapan untuk proses pembuatan, penyimpanan dan penjualan makanan dan minuman bagi umum di tempat usahanya.

Sebuah restoran harus menerapkan hubungan baik kepada pelanggan agar pelanggan merasa nyaman dan menjadi konsumen yang loyal. Untuk meraih konsumen tentunya sebuah restoran harus mempunyai keunggulan dalam bersaing, misalnya dengan promosi yang kreatif. Hal tersebut harus dipegang kokoh sebagai pelaku bisnis agar konsumen mengetahui informasi tentang restoran tersebut dan merasa nyaman serta kepercayaan terhadap restoran tersebut.

Masalah yang sering dialami oleh semua restoran yaitu penurunan jumlah konsumen. Penurunan jumlah konsumen yang melakukan pembelian mungkin terjadi karena kegiatan promosi yang dilakukan oleh restoran kurang baik. Pada dasarnya kegiatan promosi mempunyai pengaruh yang sangat penting terhadap keputusan pembelian konsumen. Salah satu restoran yang mempunyai masalah penurunan jumlah konsumen yaitu restoran Javana Bistro.

Manager Operasional Javana Bistro mengatakan bahwa hal ini diakibatkan karena "kegiatan promosi yang dilakukan oleh javana bistro tidak begitu gencar dan kompetitor yang bertambah banyak di Paris Van Java, hal tersebut berdampak terhadap revenue restoran yang terus menerus menurun". Pihak restoran tidak mengharapkan mengalami penurunan jumlah pengunjung dan revenue karena dapat mengancam eksistensi restoran, jika tidak diatasi dengan cepat akan berdampak buruk pada kelangsungan restoran. 
Salah satu upaya yang dilakukan oleh Javana Bistro untuk meningkatkan keputusan pembelian yaitu dengan adanya kegiatan promosi. Melalui kegiatan promosi perusahaan dapat berkomunikasi dengan konsumen. dengan promosi, orang yang sebelumnya tidak tertarik untuk membeli suatu produk akan menjadi tertarik dan mencoba produk sehingga konsumen melakukan pembelian.

\section{Parawisata}

Pariwisata adalah berbagai macam kegiatan wisata dan didukung berbagai faslitas serta layanan yang disediakan oleh masyarakat, pengusaha, Pemerintah dan Pemerintah Daerah. (Undang-undang RI No 10 tahun 2009 tentang kepariwisataan).

Menurut pendapat yang dikemukakan oleh Muljadi (2010:7), istilah pariwisata berasal dari dilaksanakannya kegiatan wisata (tour), yaitu suatu aktivitas perubahan tempat tingagal sementara dari seseorang, di luar tempat tinggal seharihari dengan suatu alasan apa pun selain melakukan kegiatan yang bias menghasilkan upah atau gaji.

\section{Restoran}

Menurut Bagyono (2010:65), restoran yaitu usaha jasa boga yang dikelola secara komersial, menyediakan pelayanan makan dan minum. Restoran dapat berdiri sendiri dengan membangun tempat khusus. Sementara restoran yang berada di dalam sebuah hotel pada umumnya dikelola oleh hotel itu sendiri, dan manajemennya dibawah tanggung jawab departemen makanan dan minuman (food and beverage).

Restoran adalah suatu tempat atau bangunan yang diorganisasi secara komersial, yang menyelenggarakan pelayanan dengan baik kepada semua tamunya baik berupa makanan maupun minuman (Marsum, 2005:7).

Menurut Sihite (2000:16) mengemukakan bahwa Restoran asalah suatu tempat dimana seseorang yang datang menjadi tamu yang akan mendapatkan pelayanan untuk menikmati makanan, baik pagi, siang ataupun malam sesuai dengan jam bukanya dan oleh tamu yang menikmati hidangan itu harus membayar sesuai dengan harga yang ditentukan sesuai daftar yang disediakan di restoran itu.

\section{Pemasaran}

Menurut Kotler dan Amstrong (2012:5) menyatakan bahwa "marketing is the process by which companies create value for customers and build strong customer relationship in order to capture value from customers in return". Dapat diartikan pemasaran yaitu suatu proses dimana perusahan menciptakan nilai bagi pelanggan dan membangun hubungan yang kuat dengan pelanggan dengan tujuan untuk menangkap nilai dari pelanggan sebagai imbalannya.

Menurut Daryanto (2011:1) menyatakan bahwa pemasaran adalah sautu proses sosial dan manejerial dimana individu dan kelompok mendapatkan kebutuhan dan keinginan mereka dengan menciptakan, menawarkan, dan bertukar sesuatu yang bernilai satu sama lain". 


\section{Promosi}

Menurut Agustina (2011:127) menyatakan bahwa "promosi merupakan suatu bentuk komunikasi pemasaran. Komunikasi pemasaran adalah aktivitas pemasaran yang berusaha untuk menyebarkan informasi, mempengaruhi / membujuk, dan mengingatkan pasar sasaran atas perusahaan dan produknya agar bersedia menerima, membeli, dan loyal pada produk yang ditawarkan perusahaan yang bersangkutan”.

Menurut Lupiyoadi menyatakan bahwa "Promosi merupakan salah satu variable dalam bauran pemasaran yang sangat penting dilaksanakan oleh perusahaan dalam memasarkan produk jasa. Kegiatan promosi bukan saja berfungsi sebagai alat komunikasi antara perusahaan dan konsumen, melainkan juga sebagai alat untuk mempengaruhi konsumen dalam kegiatan pembelian atau penggunaan jasa sesuai dengan kenginan dan kebutuhannya."

Ada tiga unsur pokok dalam struktur komunikasi pemasaran, yaitu:

1) Pelaku komunikasi terdiri dari pengirim (sender) atau komunikator yang menyampaikan pesan dan penerima (receiver) atau komunikasi pesan. Dalam konteks pemasaran, komunikator adalahprodusen atau perusahaan, sedangkan komunikannya adalah khalayak, seperti pasar pribadi, pasar organisasi maupun masyarakat umum (yang berperan sebagai inisiator, influencer, decider, purchaser, dan user).

2) Material Komunikasi, meliputi:

a. Gagasan merupakan materi pokok yang hendak disampaikan pengirim.

b. Pesan (message) merupakan himpunan berbagai simbol (oral, verbal atau non verbal) dari suatu gagasan. Pesan akan dapat dikomunikasikan apabila melalui suatu media.

c. Media adalah pembawa (transporter) pesan komunikasi. Pilihan media komunikasi pemasaran biasa bersifat personal maupun non personal. Media personal dapat dipilih dari tenaga konsultan, tenaga ahli professional atau masyarakat umum. Media non personal meliputi media massa (seperti radio, televisi, koran, majalah, tabloid, maupun internet). Kondisi lingkungan (gedung dan ruangan) ataupun peristiwa tertentu (hari-hari khusus dan hari-hari besar).

d. Respons merupakan pemahaman atas pesan yang diterima oleh penerima.

e. Feed-back adalah pesan umpan balik dari sebagian atau keseluruhan respon yang dikirim kembali oleh penerima pesan.

f. Gangguan merupakan segala sesuatu yang dapat menghambat jalannya proses komunikasi. Gangguan ini bias berupa gangguan fisik, masalah semantik/bahasa, perbedaan budaya, efek status dan ketiadaan umpan balik.

3) Proses Komunikasi

Proses komunikasi merupakan proses penyyampaian pesan (dari pengirim kepada penerima) maupun pengirim kembali respon (dari penerima kepada pengirim) akan memerlukan dua kegiatan, yaitu encoding (fungsi mengirim) dan decoding (fungsi menerima).

a. Encoding merupakan kegiatan merancang atau merubah gagasan yang bersifat simbolik menjadi suatu pesan untuk disampaikan kepada penerima. 
b. Decoding merupakan proses menerjemahkan, mengartikan atau menguraikan simbol sehingga pesan yang diterima dapat dipahami.

Berdasarkan pada definisi diatas maka dapat disimpulkan bahwa promosi merupakan kegiatan yang dilakukan perusahaan untuk meningkatkan keputusan pembelianbarang atau jasa melalui penyebaran informasi dan himbauan kepada konsumen untuk membeli produk tersebut.

\section{Tujuan Promosi}

Menurut Agustina (2011:127) menyatakan bahwa "Tujuan utama promosi adalah untuk menginformasikan, mempengaruhi dan mebujuk serta mengingatkan pelanggan sasaran tentang perusahaan dan bauran pemasarannya". Tujuan secara lebih rinci adalah sebagai berikut:

1. Menginformasikan yaitu berupa:

a) Menginformasikan pasar mengenai keberadaan suatu produk.

b) Memperkenalkan cara pemakaian yang baru dari suatu produk baru.

c) Menyampaikan perubahan harga kepada pasar.

d) Menjelaskan cara kerja suat produk.

e) Menginformasikan jasa-jasa yang disediakan oleh perusahaan.

f) Meluruskan kesan yang salah.

g) Mengurangi kekhawatiran dan ketakutan pembeli.

h) Membangun citra perusahaan.

2. Membujuk pelanggan sasaran, yaitu untuk:

a) Membentuk pilihan merek.

b) Mengalihkan pilihan merk.

c) Mengubah presepsi pelanggan terhdap atribut produk.

d) Mendorong pembeli untuk belanja saat itu juga.

e) Mendorong pembeli untuk menerima kunjungan wiraniaga.

3. Mengingatkan, yang terdiri dari:

a) Mengingatkan pembeli bahwa produk yang bersangkutan dibutuhkan dalam waktu dekat.

b) Mengingatkan pembeli akan tempat-tempat yang menjual produk perusahaan.

c) Membuat pembeli tetap ingat walaupun tidak ada kampanye iklan.

d) Menjaga agar ingatan pertama pembeli jatuh pada produk perusahaan.

\section{Keputusan Pembelian}

Menurut Fandy Tjiptono (2014:21) keputusan pembelian adalah sebuah proses dimana konsumen mengenal masalahnya, mencari informasi mengenai produk atau merek tertentu dan mengevaluasi seberapa baik masing-masing alternatif tersebut dapat memecahkan masalahnya, yang kemudian mengarah kepada keputusan pembelian.

Menurut Kotler dan Keller (2012:227) adalah Proses keputusan pembelian merupakan proses dimana konsumen melewati lima tahap, yaitu pengenalan masalah, pencarian informasi, evaluasi alternatif, keputusan pembelian, dan perilaku pasca pembelian, yang dimulai jauh sebelum pembelian aktual dilakukan dan memiliki dampak yang lama setelah itu. 


\section{Dimensi Keputusan Pembelian}

Pada saat konsumen mengambil keputusan pembelian sesungguhnya merupakan kumpulan dari sejumlah keputusan yang teroganisir. Dan dalam keputusan pembelian terdapat enam dimensi keputusan pembelian menurut Kotler dan Keller (2012:178) yang terdiri dari : pilihan produk, pilihan merek, pilihan penyalur, jumlah pembelian, waktu pembelian dan metode pembayaran. Dalam melaksanakan maksud pembelian, konsumen dapat membentuk lima sub keputusan diantaranya seperti : memutuskan merek yang akan dibeli, penyalur mana yang dipilih untuk membeli produk, kuantitas barang yang akan dibeli, waktu pembelian produk, dan metode pembayaran yang akan digunakan. Kotler dan Keller, 2012:178).

1. Pilihan produk, dalam hal ini perusahaan harus memusatkan perhatiannya kepada orang-orang yang berniat membeli sebuah produk serta alternatifnya yang mereka pertimbangkan. Konsumen dapat mengambil keputusan untuk memilih sebuah produk dengan pertimbangan:

a. Keunggulan produk, yaitu tingkat kualitas diharapkan oleh konsumen pada produk yang dibutuhkan dari beragam pilihan yang ada.

b. Manfaat produk, yaitu tingkat kegunaan yang dapat diperoleh konsumen pada tiap pilihan produk untuk memenuhi kebutuhannya.

c. Pemilihan produk, yaitu pilihan konsumen pada produk yang akan dibelinya sesuai dengan kualitas yang diinginkan dan manfaat yang akan diperolehnya.

2. Pilihan merek, konsumen harus menjatuhkan pilihan pada merek apa yang akan dibeli. Dalam hal ini perusahaan harus mengetahui bagaimana cara konsumen menjatuhkan pilihan terhadap sebuah merek yaitu:

a. Ketertarikan pada merek, yaitu ketertarikan pada citra merek yang sudah melekat pada produk yang dibutuhkan.

b. Kebiasaan pada merek, yaitu konsumen memilih produk dengan merek tertentu, karena telah terbiasa dengan merek tersebut pada produk yang dibelinya.

c. Kesesuaian harga, yaitu konsumen selalu mempertimbangkan harga yang sesuai dengan kualitas dan manfaat produk yang akan diperolehnya.

3. Pilihan penyalur, konsumen harus menentukan penyalur mana yang dipilih untuk membeli produk. Dalam hal ini konsumen memilih penyalur dapat dikarenakan faktor lokasi yang dekat, harga yang murah, tersedianya barang yang lengkap dan kenyamanan pada saat membeli.

a. Kemudahan untuk mendapatkan produk yang diinginkan, konsumen akan merasa lebih nyaman jika lokasi pendistribusian produk mudah dijangkau dalam waktu yang singkat.

b. Pelayanan yang diberikan, dengan pelayanan yang baik maka akan menimbulkan kenyamanan konsumen sehingga konsumen akan selalu memilih lokasi tersebut.

c. Ketersediaan barang, kebutuhan dan keiinginan konsumen terhadap produk tidak dapat dipastikan kapan terjadi namun dengan ketersediaan barang yang memadai pada penyalur akan membuat konsumen memilih untuk melakukan pembelian di tempat tersebut. 
4. Jumlah pembeliaan, konsumen dapat menentukan kuantitas barang yang akan dibeli. Dalam hal ini perusahaan harus mempersiapkan banyaknya produk yang sesuai dengan keinginan konsumen yang berbeda-beda. Karena konsumen akan menentukan :

a. Keputusan jumlah pembelian, selain keputusan pada pilihan merek yang ditentukan konsumen, konsumen juga dapat menentukan kuantitas barang yang akan dibelinya.

b. Keputusan pembelian untuk persediaan, dalam hal ini konsumen memilki produk selain untuk memenuhi kebutuhannya juga melakukan beberapa tindakan persiapan dengan sejumlah persdiaan produk yang mungkin dibutuhkannya pada saat mendatang.

5. Waktu pembelian, pada saat konsumen menentukan waktu pembelian dapat berbeda-beda yaitu:

a. Kesesuaian dengan kebutuhan, ketika mereasa butuh sesuatu dan merasa perlu melakukan pembelian.

b. Keuntungan yang dirasakan, ketika konsumen membeli kebutuhannya akan suatu produk pada saat tertentu, maka pada saat itu konsumen akan merasakan keuntungan sesuai dengan kebutuhannya melalui produk yang dibelinya.

c. Alasan pembelian, setiap produk memiliki alasan untuk memenuhi kebutuhan konsumen pada saat konsumen membutuhkannya.

6. Metode pembayaran, konsumen dapat menetukan metode pembayaran yang akan digunakan pada saat transaksi pembelian. Konsumen mungkin akan menggunakan cara pembayaran: bayar tunai, cek, kartu kredit, kartu debit, kartu ATM, kredit melalui lembaga keuangan dan kredit melalui toko.

\section{Hasil dan Diskusi}

Berdasarkan hasil kajian serta penelitian mengenai promosi terhadap keputusan pembelian, maka dihasilkan temuan-temuan teoritis seperti berikut.

1. Berdasarkan temuan penelitian penulis bahwa promosi penting dalam mepengaruhi konsumen. Hal ini memperkuat konsep yang mengemukakan bahwa "promosi merupakan salah satu faktor penentu keberhasilan suatu program pemasaran. Betapa berkualitasnya suatu produk, bila konsumen belum pernah mendengarnya dan yakin bahwa produk tersebut akan berguna bagi mereka, maka mereka tidak akan pernah membelinya (Hurriyati, 2010:57).

2. Berdasarkan temuan penelitian yang bersifat teoritis penulis memperkuat konsep promosi. Menurut Kotler dan Bowen (2010:358) menyatakan bahwa "Promotion mix consist of the blend of advertising, public relation, word of mouth, personal selling tools that the company use to communicate customer value and build customer relationship persuauvely.

3. Berdasarkan temuan penelitian, maka penulis dapat memperkuat konsep keputusan pembelian dengan mengambil konsep Kotler dan Keller (2012:173), yang menyatakan bahwa keputusan pembelian merupakan proses konsumen untuk melakukan pembelian suatu produk atau jasa yang 
ditawarkan. Konsumen akan mengambil keputusan sesuai dengan kebutuhan dan keinginan. Maka, mengetahui dan memahami apa yang diinginkan konsumen bagaimana mereka bertindak merupakan bagian penting dari setiap perusahaan untuk menarik konsumen.

Berdasarkan hasil penelitian diperoleh pengaruh promosi terhadap keputusan pembelian sudah baik secara simultan (keseluruhan) maupun parsial (individu). Adapun pengaruh antara variabel yakni sebagai berikut.

1. Hasil penelitian deskriptif mengenai promosi di Javana Bistro, dihasilkan temuan dimensi promosi yang memberikan pengaruh paling tinggi adalah indikator informasi dari mulut ke mulut, sedangkan yang memberikan pengaruh paling rendah ada pada indikator pemasaran langsung. Berdasarkan hasil penelitian yang dilakukan oleh penulis, word of mouth memiliki pengaruh yang baik terhadap keputusan pembelian

2. Hasil penelitian secara simultan (keseluruhan) menunjukkan bahwa program promosi memiliki pengaruh positif terhadap keputusan pembelian Hasil penelitian secara simultan (keseluruhan) menunjukkan bahwa program promosi memiliki pengaruh positif terhadap keputusan pembelian

\section{Kesimpulan}

Berdasarkan analisis data dan pembahasan hasil penelitian yang telah dilakukan, maka dapat ditarik beberapa kesimpulan sebagai berikut:

1. Gambaran mengenai promosi dari penyebaran kuesioner terhadap responden di Javana Bistro diperoleh bahwa skor tertinggi dicapai dalam hal informasi dari mulut ke mulut sebagian besar responden berpendapat cukup baik. Sedangkan skor terendah terdapat dalam hal pernyataan pemasaran langsung.

2. Gambaran mengenai keputusan pembelian dari penyebaran kuesioner terhadap responden di Javana Bistro yang paling tinggi menurut responden adalah metode pembayaran sebagian responden memberi pendapat cukup baik. Tanggapan responden terhadap keputusan pembelian yang paling rendah menurut responden adalah pilihan produk.

3. Promosi berpengaruh signifikan terhadap keputusan pembelian, berdasarkan pengujian secara parsial yang menunjukan bahwa promosi berpengaruh positif dan signifikan terhadap keputusan pembelian.

\section{Daftar Pustaka}

http://www.kemenpar.go.id/userfiles/Lapbul\%20Desember\%202015_klasik(revisi).p df/diaksespada:25februari2016:10:56).

UU No.10 Tahun 2009 tentang Kepariwisataan.

Muljadi A.J. 2010. Kepariwisataan dan perjalanan. Jakarta: PT Raja Grafindo.

Bagyono. 2010. Pariwisata dan Perhotelan. Bandung: Alfabeta.

Marsum. 2005. Restoran dan Segala Permasalahannya. Yogyakarta: Andi Offset.

Sihite, Richard. 2000. Hotel Management. Surabaya : SIC.

Kotler, Philip and Gary Amstrong. 2012. Prinsip-prinsip Pemasaran. Edisi 13 Jilid 1. Jakarta : Erlangga. 
Daryanto. 2011. Manajemen Pemasaran. Bandung: PT sarana Tutorial Nurani Sejahtera.

Agustina. 2011. Manajemen Pemasaran. Bandung : Alfabeta.

Tjiptono, Fandy. 2014. Pemasaran Jasa-Prinsip, Penerapan dan Penelitian. Yogyakarta: CV. ANDI.

Hurriyati. 2010. Bauran pemasaran dan loyalitas konsumen. Bandung: Alfabeta. 